Estrin, S., Meyer, K.E., Wright, M. \& Foliano, F. (2008): Export Propensity and Intensity of Subsidiaries in Emerging Economies, International Business Review, (IBR, forthcoming).

\title{
Export Propensity and Intensity of Subsidiaries in Emerging Economies
}

\author{
Saul Estrin \\ Department of Management, London School of Economics \\ Houghton Street, London WC2A 2AE, U.K. \\ s.estrin@1se.ac.uk, www.lse.ac.uk
}

\author{
Klaus E. Meyer \\ School of Management, University of Bath \\ Claverton Down, BA2 7AY, U.K. \\ k.meyer@reading.ac.uk,www.klausmeyer.co.uk

\begin{abstract}
Mike Wright
Centre for Management Buy-out Research

Nottingham University Business School

Jubilee Campus, Nottingham NG8 1BB, U.K.

mike.wright@nottingham.ac.uk
\end{abstract}

\author{
Francesca Foliano \\ University of Tor Vergata \\ Via Columbia 2, Roma, Italy \\ francescafoliano@hotmail.co.uk
}

forthcoming in:

International Business Review

Final version: April 2008

Acknowledgement: We thank for support for the data-collection of this project from Social Science Foundation (SSF, Denmark) under grant number 24-01-0152, and the Department for International Development (UK) under DFID/ESCOR project no. R7844, Center for New and Emerging Markets, London Business School. Two anonymous reviewers, Igor Filatotchev, Mike Peng, Keith Brouthers, Simon Burke, Klaus Uhlenbruck and Trevor Buck and participants of the AIB conference in Indianapolis and a seminar at Reading University provided helpful comments. 


\title{
Export Propensity and Intensity of Subsidiaries in Emerging Economies
}

\begin{abstract}
We extend the theory of the multinational enterprise and the institutional perspective of strategy by exploring subsidiary-specific advantages as a driver of subsidiary exports. We distinguish between the factors influencing whether or not subsidiaries are exporting (export propensity) and those determining the share of sales that are exported (export intensity). The former are argued to be largely associated with the relative resource position of the subsidiary and the latter primarily with the character of the host institutional environment.

We provide empirical support for these arguments through a Heckman two-stage selection model estimation using a unique primary dataset of foreign owned affiliates in Hungary, Poland, India and South Africa, Egypt and Vietnam. In particular, the quality of the host institutional environment does not affect export propensity which depends on subsidiary specific advantages in terms of geographic location, acquired resources and small scale of the parent MNE. However, export intensity is lower where the institutional environment has a higher level of economic freedom.
\end{abstract}


Estrin, S., Meyer, K.E., Wright, M. \& Foliano, F. (2008): Export Propensity and Intensity of Subsidiaries in Emerging Economies, International Business Review, (IBR, forthcoming).

\section{Subsidiary Export Propensity and Intensity in Emerging Economies}

\section{Introduction}

Multinational enterprises (MNEs) allocate economic activities across countries, often establishing a system of production sites in multiple countries that involves both trading between these units and exporting to third countries (Casson, 2000). Subsidiary location and exporting are thus cornerstones of international strategies by which MNEs exploit comparative advantages of different locations (Caves, 1974; Dunning, 1998; Dunning \& Lundan, 1998). Yet their mutual interdependence has rarely been analyzed theoretically or empirically.

MNEs create networks of subsidiaries that are interconnected by knowledge and trade flows (Adler \& Hashai, 2007). Their activities, and exporting in particular, depend on the subsidiary's role within that network. At the outset, this role is typically defined by corporate headquarters, but over time it may evolve with initiatives by the subsidiary itself (Birkinshaw, 1996; Birkinshaw \& Hood, 1998). In this process, the local host environment moderates the actual activities of a subsidiary (Andersson, Forsgren \& Pedersen, 2001; Wright, Filatotchev, Hoskisson \& Peng, 2005), leading to the creation of subsidiary-specific advantages (Rugman \& Verbeke, 2001).

The institutional perspective of business strategy emphasizes the institutional framework as a key factor influencing the strategies and operations of foreign investors (Luo \& Peng, 1999; Peng, 2003; Chung \& Beamish 2005; Narayanan \& Fahey, 2005; Meyer et al., 2008). Local institutions may facilitate the development of resources and capabilities that contribute to the subsidiary's success, and possibly even generate new capabilities benefiting the parent firm (Meyer \& Peng, 2005). Local knowledge may enable subsidiaries to identify new market opportunities that the parent company cannot achieve directly (London \& Hart, 2004). In consequence, foreign investors may modify their strategies, notably locational choices (Bevan, Estrin \& Meyer, 2004; Meyer \& Nguyen, 2005) and entry modes (Brouthers \& Brouthers, 2003; Meyer, 2001; Henisz, 2003; Meyer et al., 2008). We extend this line of work 
Estrin, S., Meyer, K.E., Wright, M. \& Foliano, F. (2008): Export Propensity and Intensity of Subsidiaries in Emerging Economies, International Business Review, (IBR, forthcoming).

by arguing that host economy institutions are even more important for operational than for strategic decisions, notably for the proportion of sales that are exported (export intensity) rather than the choice of whether or not sales are exported (export propensity).

Exporting is an important element of subsidiary and MNE strategy (Filatotchev, Demina, Wright \& Buck, 2001; Filatotchev, Stephan \& Jindra, 2008). Studies of the determinants of the choice to export have primarily focused on domestic enterprises, both in developed economies (Cavusgil \& Neven, 1981; Bonaccorsi, 1992; Leonidou \& Katsikeas, 1996; Majocchi, Bacchiocchi \& Mayrhofer, 2005; Wu, Sinkovics, Cavusgil \& Roath, 2007) and emerging economies (Aulakh, Kotabe \& Teegen, 2000; Das, Roberts \& Tybout, 2007; Wagner, 2007). However, their insights may not be transferable to subsidiaries of MNEs that are also influenced by their foreign parent firm. Moreover, these studies mostly focus on the characteristics of the firm, rather than its local environment.

The local environment, however, is crucial for explaining subsidiary exports in emerging economies. Firstly, the locational advantages of the host location with respect to inputs into the production process, notably labor, determine the kind of operations that are likely to be located there (Dunning, 1998). For example, low-cost semi-skilled labor or rich natural resources may attract investments that specifically aim to exploit arbitrage opportunities (Ghemawat, 2007). Moreover, the institutional context shapes the opportunities to exploit such opportunities, For instance, recent work shows that ownership and governance structures have an important influence on export intensity (Filatotchev, et al., 2001; 2008).

We analyze why MNEs choose to export from their subsidiaries rather than focus on production in subsidiaries to meet demands from within the host economy. Within this research question, we make an important distinction between export propensity and intensity because the triggers that initiate exporting are likely to differ from determinants of the efforts put into developing the export business (Bonaccorsi, 1992; Greenaway, Sousa \& Wakelin, 2004; Das, Roberts \& Tybout, 2007). Thus we examine (1) what determines whether or not MNE's subsidiaries in an emerging economy are exporting (i.e. export propensity), (2) among exporting subsidiaries, what determines the extent to which exports contribute to their sales 
Estrin, S., Meyer, K.E., Wright, M. \& Foliano, F. (2008): Export Propensity and Intensity of Subsidiaries in Emerging Economies, International Business Review, (IBR, forthcoming).

(i.e. export intensity)? We employ a Heckman two-stage selection procedure to address possible issues of bias in the joint estimation of the intensity and the propensity equations.

The novel data set employed in the empirical work is another important feature of the paper. We selected six major emerging economies (Egypt, Hungary, India, Poland, South Africa and Vietnam). These countries were chosen because they were all recipients of significant FDI flows over the sample period. Moreover, they all undertake major liberalization/reform policies in the 1980 s or 1990 s, to make them relatively attractive FDI hosts for their region. Despite their similarities, the set of countries offers a high degree of variation of institutional development, our focal variable. The countries have liberalized domestic and international markets at different speeds throughout the 1990s, which culminated in two of the economies - Hungary and Poland - acceding to the European Union. ${ }^{1}$ We collected the data using a customized survey instrument administered to a representative sample of all foreign subsidiaries set up during the period 1990-2000 in each of the selected countries, and complemented them with archival data for key explanatory variables (Estrin \& Meyer, 2004; Meyer \& Estrin 2007).

We offer a number of contributions. First, we develop the theory of the MNE by exploring the strategic linkages between subsidiary location and subsidiary exports, thus advancing the notion of subsidiary-specific advantages. Second, we add to calls to integrate different theoretical perspectives when considering international strategy in emerging economies (Wright et al., 2005; Meyer \& Peng, 2005) by integrating the theory of the MNE with an institutional perspective. Third, this study is one of the first distinguishing between the factors influencing whether or not subsidiaries are exporting, and those determining the scale of these exports. More specifically, we show that the relative position of the subsidiary within the MNE network drives export propensity, while the host market environment, especially the institutional framework, shapes export intensity in the subsidiaries that export.

\footnotetext{
${ }^{1}$ Although this happened shortly after our data-collection, preparations were well-advanced at the time of our study.
} 
Estrin, S., Meyer, K.E., Wright, M. \& Foliano, F. (2008): Export Propensity and Intensity of

Subsidiaries in Emerging Economies, International Business Review, (IBR, forthcoming).

Our findings are relevant to managers aiming to optimize their global network, and to governmental policymakers aiming to increase their country's exports.

\section{Subsidiary-specific Advantages}

The theory of the MNE posits that MNEs compete on the basis of unique assets they control and that they transfer across national boundaries. These assets are known in the literature as ownership advantages (Dunning 1998; Dunning \& Lundan, 2008), firm-specific advantages (Rugman 1996), or resources and capabilities (Barney, Wright \& Ketchen, 2001). They enable firms to be competitive in host markets despite facing competitive disadvantages arising from their liability of foreignness (Zaheer, 1995).

This literature posits that firms establish subsidiaries, rather than export or license their goods or services, if the firm-specific advantages they wish to transfer are subject to high transaction costs (Buckley \& Casson, 1976; 1998; Brouthers \& Hennart, 2007). Thus, firms establish subsidiaries when they have firm-specific advantages that are valuable elsewhere, and the best way to transfer them is by an internal mode of coordination.

If these conditions hold, why then do subsidiaries export? Subsidiaries are building blocs in an interdependent network of business units of the MNE (Buckley \& Casson, 1976; Casson, 2000). For a subsidiary to export, it must not only overcome the liability of foreignness in any market in which it sells, but also at its own location. More specifically, it must be competitive vis-à-vis other units of the MNE, and it must be competitive vis-à-vis local firms in its host country - in addition to being competitive vis-à-vis local firms in the target market.

How can subsidiaries build a position that provides such advantages? The resource position of the subsidiary combines resources of the parent with location-bound advantages of the host economy. Subsidiaries would export if their resource endowment makes them best suited within the network of the MNE to serve particular markets. Thus, subsidiary exports arise from 'subsidiary-specific advantages' (Rugman \& Verbeke, 2001) that are grounded in resources that are both firm-specific and location-bound. 
Estrin, S., Meyer, K.E., Wright, M. \& Foliano, F. (2008): Export Propensity and Intensity of Subsidiaries in Emerging Economies, International Business Review, (IBR, forthcoming).

One source of subsidiary-specific advantages, relative to other units of the MNE, is its embeddedness in the host economy, and in the regional economy beyond the host country. Thus, subsidiaries may develop regional business competences that transcend national markets but are more specific than global business knowledge. These region-specific advantages (Rugman \& Verbeke, 2003), relative to other units of the MNE, are likely to be important since trade in goods continues to be subject to transportation costs even in the age of globalization (Ghemawat, 2007). Subsidiaries thus are likely to serve other countries in the region if the MNE does not have subsidiaries in each country of the region, and it is geographically distant from headquarters of the MNE. The subsidiary may thus attain a 'regional mandate', and export to neighboring countries. This possibility arises in particular for subsidiaries located within a regional bloc to which the MNE's country of origin does not belong.

Subsidiary-specific advantages are also deliberately created, for instance when an MNE acquires a local firm. Especially firms with internationally valuable assets attract foreign acquirers who then utilize the acquired resources beyond the host economy (Anand \& Delios, 2002; Uhlenbruck, 2004). An acquired operation has its inherited resources and organizational structures, including possibly export market relationships, which form a basis for subsidiary-specific advantages.

Subsidiaries of large MNEs are less likely to have relative advantages vis-á-vis other units of the MNE, which may have operations in each target market. Smaller MNEs may be more resource-constrained and thus operate from a smaller number of operations (Barkema \& Vermeulen, 1998). Hence, large MNEs may establish extensive networks of subsidiaries focusing on specific markets, while small MNEs employ a regional hub strategy with subsidiaries exporting to multiple markets.

The exploitation of subsidiary-specific advantages is shaped by the specific local context. In particular, the resource endowment of the host economy and its institutional framework moderate the characteristics and survival of foreign subsidiaries, especially in emerging economies (Chung \& Beamish, 2005; Meyer \& Peng, 2005). The institutional 
Estrin, S., Meyer, K.E., Wright, M. \& Foliano, F. (2008): Export Propensity and Intensity of

Subsidiaries in Emerging Economies, International Business Review, (IBR, forthcoming).

environment shapes the attractiveness of the local market, for instance by moderating market transaction costs, and facilitating demand growth. Hence institutions influence business opportunities, and thus domestic sales growth. Thus exports may grow slower compared to local sales where local markets are efficient and pose few barriers to entry.

This interaction between resources of the parent and the local context in creating subsidiary-specific advantages implies that the determinants of 'what subsidiaries do?' can be quite different from 'how much do they do?' For instance, Davis and Meyer (2004) found that the determinants of whether subsidiaries engage in $R \& D$ differ from the determinants of $R \& D$ intensity - in particular, that government support impacts subsidiaries' incidence of R\&D but not its level, while competitive conditions affect the level but not the incidence. We thus hypothesize that explanatory factors vary in determining whether or not subsidiaries export at all (propensity), and, if they do, how much they export (intensity). We argue that export propensity is associated with the relative resource position of the subsidiary, which in turn depends on its geographic distance from the MNE parent, unique resources created through an acquisition, and the degree of specialization within the MNE network. On the other hand, we propose that export intensity, given the decision to export, is associated with the nature of the local environment.

\section{Hypothesis Development}

\section{Subsidiary-specific advantages}

When do subsidiaries in emerging economies have unique location-bound firm-specific advantages that allow them to develop a mandate of selling beyond domestic markets? The first source of such advantages arises from geography.

An MNE would assign regional export mandates when it does not have subsidiaries in each market, and a subsidiary near the market is better positioned to serve those markets than the operation in the country of origin. This would be the case when the focal market is not close to another major unit of the MNE, i.e. where large geographic distances are

involved. In distant markets, MNEs may use a multi-country strategy where they serve 
Estrin, S., Meyer, K.E., Wright, M. \& Foliano, F. (2008): Export Propensity and Intensity of

Subsidiaries in Emerging Economies, International Business Review, (IBR, forthcoming).

multiple countries from one production site. As most MNEs are strongest in their home region (Rugman \& Verbecke, 2003), operations in distant markets have a more peripheral nature, and may operate from regional hubs. Moreover, geographically distant operations are more likely to enjoy substantially different factor endowments, which provide a basis for international trade between parents and subsidiaries (Ozawa, 1978).

In distant markets, exporters may face greater problems in obtaining knowledge about local market opportunities, in coordinating sales strategies and in monitoring agents (Ellis, 2007; Wu et al., 2007). Correspondingly, geographically distant subsidiaries may have the regional knowledge to make adaptations and innovations to accommodate the local market conditions that would be harder for the parent firm to acquire (London \& Hart, 2004; Meyer \& Peng, 2005; Harzing \& Noorderhaven, 2006). Subsidiaries in emerging economies may especially face a lower knowledge gap with adjacent countries than their parent MNEs since these economies may have similar economic and institutional contexts (Lee \& Beamish, 1995). Therefore, subsidiaries of distant MNEs may be more likely to attain a mandate to export to other countries in the region (Birkinshaw \& Hood, 1998). Moreover, as subsidiary managers find new ways to combine local and parent resources and become aware of opportunities in adjacent countries, their mandates may be developed to include exporting (Frost, Birkinshaw \& Ensign, 2002).

Thus, in geographically distant regions, MNEs may pursue a multi-country strategy serving many countries from one site, thus serving these markets by exports from a regional hub:

H1: Subsidiaries of geographically more distant parent MNEs are more likely to export [propensity].

Subsidiary-specific advantages may also be created when MNEs acquire local firms to access specific knowledge and resources of value for the global corporation. Resources of potential value in international competition are often embedded in existing organizations, as 
Estrin, S., Meyer, K.E., Wright, M. \& Foliano, F. (2008): Export Propensity and Intensity of

Subsidiaries in Emerging Economies, International Business Review, (IBR, forthcoming).

well the local context, especially if they involve human capital (Anand \& Delios, 2002; Meyer \& Peng, 2005). Acquired subsidiaries have a repository of knowledge, resources, business relationships and an organizational history (Barkema \& Vermeulen, 1998), which new owners would typically want to continue to exploit (Uhlenbruck, 2004). In particular, $\mathrm{R} \& \mathrm{D}$ has been shown to be continued, though not necessarily at the pre-acquisition level (Belderbos, 2003; Davis \& Meyer, 2004). In fact, capabilities with demonstrated relevance beyond the local context may motivate an acquisition in the first place (Anand \& Delios, 2002).

Acquisitions are at the time of entry fully operating enterprises that the new owners may restructure to fit their needs. Where the local affiliate has valuable assets, such as knowledge of adjacent markets and international customer relationships, they are unlikely to be discarded by an acquirer, even if they are peripheral to the acquirers' global strategy. Replacing them with routines from the parent may be both difficult and unproductive (Fiol \& Lyles, 1985), especially in an emerging economy context. Where acquired firms have export market positions, they are thus likely to continue them (Uhlenbruck, 2004). ${ }^{2}$ In contrast, greenfield projects provide opportunities to design new operations by replicating organizational structures and processes, such as to serve a particular local market (Hennart \& Park, 1993). Such a replication approach may be less suitable to develop exports to other emerging economies. Thus, based on inherited operations, acquired subsidiaries are more likely than greenfield projects to export:

H2: Acquired subsidiaries are more likely to export [propensity].

The role of a subsidiary depends to a large extent on the strategy guiding the parent MNE’s network (Bartlett \& Ghoshal, 1989; Birkinshaw \& Hood, 1998). In particular, MNE networks vary in the autonomy and specialization of their constituent business units. Some

\footnotetext{
${ }^{2}$ Even if not all acquired firms have been exporting prior to the acquisition, the average firm would have some exports.
} 
MNE networks include sales operations in each country, while others rely to a large extent on a small number of production sites serving multiple markets. Large MNEs may have sufficient resources and capabilities to establish a subsidiary in each of its target markets (Barkema \& Vermeulen, 1998). Each specific subsidiary would then be less pivotal for their global system of production and trade. They would thus be less in need of regional hubs, or of production sites supplying their global market. In contrast, smaller MNEs may employ a regional hub strategy serving multiple countries by exporting from one location, or in fact establishing a single manufacturing site in a low cost location serving its global network.

Large scale of the global network thus allows for higher degrees of specialization and the establishment of specific subsidiaries for each market. Most of these subsidiaries would aim to serve a particular local market rather than engage in exports. Their knowledge and resources may be focused on serving the local markets. However, if they export, they are

likely to serve a specialized supplier role within the MNE, and thus export a large share of their output. On the other hand, smaller MNEs may have less specialization among subsidiaries, with each subsidiary serving a wider range of domestic and nearby foreign markets, and with these export markets being more important in the overall sales of the subsidiary.

H3a: Subsidiaries of large MNEs are less likely to export [propensity].

H3b: Exporting subsidiaries of large MNEs export a larger share of their sales [intensity].

\section{Local Institutional Environment}

The resources of a subsidiary are developed in close interaction with both the MNE parent and the local environment (Birkinshaw \& Hood, 1998; Luo, 2003). When MNEs establish foreign operations, these are adapted to the local context, especially the institutional framework (Gomes-Casseres, 1990; Meyer, 2001; Bevan, Estrin \& Meyer, 2004; Brouthers amd Hennart, 2007). Moreover, the actual market position and sales growth in the subsidiary's various markets is even more influenced by local conditions. For example, 
Estrin, S., Meyer, K.E., Wright, M. \& Foliano, F. (2008): Export Propensity and Intensity of

Subsidiaries in Emerging Economies, International Business Review, (IBR, forthcoming).

specific regulation regarding advertising, health and safety, or export taxation may substantially affect the costs of sales.

The institutional framework is particularly important for business strategies in emerging economies (Luo \& Peng, 1999; Wright et al., 2005; Meyer \& Peng, 2005). They are typically characterized by weaker property rights and high enforcement costs (La Porta, Lopez-de-Silanes, Shleifer \& Vishny, 1998), which may increase opportunistic behavior. Moreover, lack of reliable information systems increases information asymmetries, while inefficient or corrupt administrative systems create direct costs or efficiency losses - all of which contribute to higher costs of doing business. However, emerging economies vary in the nature of their institutional environments, which moreover are evolving over time (Chung \& Beamish, 2005).

Foreign investors seeking an optimal location for an export-oriented venture may consider favorably an environment where institutions support the efficiency of markets. This may for example reduce the costs of procurement of local or imported inputs, including labor, and facilitate establishment processes, e.g. by lowering the transaction costs of building a new factory or acquiring an existing business entity. Hence, efficient institutions are a form of locational advantage that helps attract export-oriented foreign investment (Dunning \& Lundan, 2008). Similarly, trade liberalization policies, including those in the form of regional trade arrangements, would help attract investors targeting these regional markets.

On the other hand, a market-supporting institutional environment in the host country eases local market access, for instance by facilitating access to distribution channels, and by preventing local incumbents from using relationships with governmental authorities to protect their markets. In such contexts, foreign affiliates may thus face better opportunities for growth by developing their local market position. In contrast, where market institutions are weak, exporting may help in gaining legitimacy with local authorities eager to promote national competitiveness and their balance of payment position (Luo, 2003). Hence: 
Estrin, S., Meyer, K.E., Wright, M. \& Foliano, F. (2008): Export Propensity and Intensity of

Subsidiaries in Emerging Economies, International Business Review, (IBR, forthcoming).

H4a: Subsidiaries in institutional contexts with higher levels of economic freedom are more likely to export [propensity].

H4b: Exporting subsidiaries in institutional contexts with higher levels of economic freedom export a lower share of their sales [intensity].

FIGURE 1 APPROXIMATELY HERE

\section{METHOD AND DATA}

\section{Analytical approach}

To test our hypotheses, summarized in Figure 1, we first analyze a subsidiary's export propensity, i.e. a categorical variable indicating whether or not the subsidiary exports. Second, for the subset of exporting firms, we examine the factors influencing export intensity, i.e. export sales as a percentage of the affiliate's total sales.

However, in our model we must take into account the possibility that the selected sub-sample of affiliates with positive exports is non-random. This happens when the unobservable factors determining export propensity are correlated with the unobservables determining export intensity or in other words, when the disturbances of the two equations representing, respectively, export propensity and export intensity are not independent, which would lead to "sample selection bias". Thus, our model is:

$$
\begin{aligned}
\text { Intensity }_{j}^{*} & =X_{j} \beta+u_{1 j} \\
\text { Propensity }_{j}^{*} & =Z_{j} \gamma+u_{2 j} \\
\text { Propensity }_{j} & =1 \text { if } Z_{j} \gamma+u_{2 j}>0 \\
& =0 \text { otherwise } \\
\text { Intensity }_{j} & =\text { Intensity }_{j} \text { if Propensity }=1 \\
& =0 \text { otherwise }
\end{aligned}
$$

Equation (1) represents the latent endogenous variable with observed counterpart described in equation (4). Equation (2) represents the selection process which determines whether the affiliate exports and is associated with the indicator function (3). Therefore the 
problem of sample selection bias, corresponding to an omitted variable problem, occurs when, while estimating the intensity equation only over the selected sub-sample, $\mathrm{E}\left(u_{1 j} \mid\right.$ Propensity $_{j}=$ $1)=\mathrm{E}\left(u_{l j} \mid u_{2 j}\right) \neq 0$ and correlated with the explanatory variables. In order to both test and address the sample selectivity bias we employ the Heckman two-stage procedure (Heckman, 1976; Greene 2000: 926-37).

In the first step, we estimate with a Probit the propensity equation for the whole sample; thus we obtain a value for the truncated mean $\mathrm{E}\left(u_{1 j} \mid u_{2 j}\right)$ given by the generalized residuals of the Probit for the affiliates with positive exports. In the second step, we estimate with OLS the intensity equation over the sub-sample given the decision to export, after having included the generalized residuals as an additional variable. The coefficient of this additional variable is a function of the correlation between the two disturbances of the model; therefore if significant, it indicates the existence of the sample selection problem and the direction of this correlation whereas, if not significant, rules out the possibility of non-random subsample. A Heckman procedure has been applied to similar study designs, for instance to investigate the pattern of exports by local firms (Greenaway et al., 2004; Das, et al., 2007) and to examine exporting behaviour by venture capital backed firms (Lockett, Wright, Burrows, Scholes \& Paton, 2008).

The Heckman procedure requires us to have different variables in the first and second equations, the selection of which has to be driven by theory. For the model to be identified, we need to identify at least one factor that affects the propensity to export and not the export intensity. Our hypotheses derived from theory suggest that geographical distance and acquisition affect only the propensity to export. Both parent size and economic freedom are argued to be associated with both propensity and intensity. ${ }^{3}$

\footnotetext{
${ }^{3}$ We did, however, conduct additional tests with other omitted variables and found that these omitted variables were not significant at all, and the choice of omitted variable did not substantively affect the key results.
} 
Estrin, S., Meyer, K.E., Wright, M. \& Foliano, F. (2008): Export Propensity and Intensity of Subsidiaries in Emerging Economies, International Business Review, (IBR, forthcoming).

\section{Sample}

Our study uses a novel data set created by merging data from two recent surveys of MNE subsidiaries in emerging economies (Estrin \& Meyer, 2004; Meyer \& Estrin 2007). We selected six emerging economies from all over the world to obtain a high variation across institutional contexts. The base population for both surveys was all registered foreign investors established within ten years before the survey, with a minimum employment of ten persons, and minimum foreign equity stake of $10 \%$. The base populations were constructed from local databases in each of the six countries using matching criteria.

The first questionnaire was administered in Egypt, South Africa, India and Vietnam between November 2001 and April 2002 by local research institutions. The questionnaire was sent to a stratified random sample drawn from the base population in each country. In most cases, the questionnaire was followed up by sending specifically trained assistants to interview the $\mathrm{CEO}$ or an appropriate senior manager, though some questionnaires were received by mail. Response rates were $10 \%$ in Egypt, $11 \%$ in India, $23 \%$ in Vietnam, and $31 \%$ in South Africa, which is comparable to other surveys in emerging economies. The sample was stratified by industrial sectors to ensure that the sectoral distribution of firms closely resembled the distribution for the population. Within each sector, firms were chosen randomly (Estrin \& Meyer, 2004; Meyer et al., 2008). We replicated the data collection process in a second study in Hungary and Poland in the year 2002, such that we obtained matching samples (Meyer \& Estrin 2007). The return rates were approximately $10 \%$ in Poland and $22 \%$ in Hungary. The sample was found to be representative of the population. We excluded the natural resource sector with three observations because this sector emerged as an outlier in the sample.

After excluding observations with missing values, the final usable sample comprises 494 affiliates. This is quite a large sample for questionnaire survey based research in emerging economies. The missing values affect in particular small parent firms for which information on parent-specific data is less available. This seems unlikely to bias the estimates, albeit we shall be careful to make inferences about small parent firms. 


\section{INSERT FIGURE 2 NEAR HERE}

\section{Variables}

\section{Dependent variables}

The pattern of exports of the surveyed firms is shown in Figure 2. As expected, the variable has a non-normal distribution. A high proportion of subsidiaries do not export, ranging from $32.1 \%$ in South Africa to $47.9 \%$ in Poland. A small number of subsidiaries are set up solely to export, notably in countries with low labor costs, India (27.5\%) and Vietnam (35.5\%). We thus construct the dependent variables as follows: export propensity is captured by a binary variable equal to 1 for exporting subsidiaries, zero otherwise; export intensity is measured by the export sales as a percentage of total sales of the affiliate (and not defined if export propensity is zero).

\section{INSERT TABLE 1 NEAR HERE}

\section{Independent variables}

The analysis combines data from the questionnaire with archival data to avert common method problems (Podsakoff, MacKenzie, Lee \& Podsakoff, 2003). The definitions and measurement of the independent variables are summarized in Table 1. To test our hypothesis 2 , we include a dummy derived from the questionnaire specifying how the affiliate was initially established in the host country. The question provided four options: full acquisition, partial acquisition, de novo joint venture and wholly-owned greenfield entry. We code the variable as a dummy, with acquisition equal to unity for both partial and full acquisitions and otherwise zero. The size of the foreign parent (H1) is measured by its worldwide employment, which we specify in logarithmic form because tests show that the underlying relationship is non-linear. 
Archival data are used for the other two focal independent variables. Geographic distance $(\mathrm{H} 2)$ between the home country of the parent MNE and the host country is measured by the geographic distance in kilometers. The strength of the institutional context (H4) of the host country was measured using the economic freedom index developed by the Heritage Foundation (www.heritage.org/index), using the version scaled from 0 to 100 introduced in 2007. This composite measure identifies a range of economic freedom measures, and thus captures both domestic institutions and the openness to the world economy, for instance in the item trade freedom. ${ }^{4}$ As these institutional conditions may vary both over time in dynamic emerging economies as well as across countries, we measure this variable at the date closest to time of entry for each firm.

\section{Control variables}

In order to ensure that an effect detected for institutional factors is not actually caused by other country-level influences, we introduced the GDP in the host country as a control variable, in logs because the underlying relationship proves better specified in this form. We control for the intensity of competition in the domestic market, as indicated via our questionnaire on a five-point scale. We would expect that greater host economy competition in product markets would motivate greater exports. We also consider the character of the exports with a variable that indicates whether the subsidiary exports to other parts of the MNE's network. We expect subsidiaries that are more closely integrated into the supply chain of the parent MNE to export relatively more. We also control for whether the executives of the affiliate had previously worked for the parent company, because higher levels of parent control may be associated with greater integration and thus higher export orientation (Filatotchev et al., 2008).

Several variables control for the resources of the foreign parent and those it may access at its home location. Its expenditure on $R \& D$ as a percentage of sales is based on a

\footnotetext{
${ }^{4}$ The index incorporates nine dimensions of economic freedom: regulation, business freedom, fiscal freedom, government size, monetary freedom, investment freedom, property rights, freedom from corruption and labor freedom.
} 
Estrin, S., Meyer, K.E., Wright, M. \& Foliano, F. (2008): Export Propensity and Intensity of

Subsidiaries in Emerging Economies, International Business Review, (IBR, forthcoming).

seven point categorical variable where $1=0-0.5 \% ; 2=0.5-1 \% ; 3=1-2 \% ; 4=2-4 \% ; 5=4-8 \%$; $6=8-15 \%$; and $7=$ over $15 \%$. We expect MNEs with such intangible resource advantages to produce closer to their R\&D centers, and thus export from emerging economy subsidiary. For parent experience, the questionnaire reports whether the MNE had prior commercial experience in the host country before setting up the subsidiary, which we specify as a zeroone dummy variable. The parent economy GDP per capita can proxy for labor cost differences, and is expected to have a positive impact on exports. To control for industry effects we introduce two dummy variables taking the value one if the affiliate company is operating in respectively the light and heavy manufacturing sector and zero otherwise, using the service sector as a base case.

\section{INSERT TABLES 2 AND 3 NEAR HERE}

Table 2 reports the descriptive statistics for the variables used in the analysis and Table 3 provides the matrix of correlation coefficients and VIF scores. Correlations between the independent variables were all below 0.4. In order to consider the possible impact of multicollinearity, VIF factors were calculated, and were generally found to be below 2, suggesting that multicollinearity was not for the most part an issue (see Hair et al, 1998).

\section{INSERT TABLE 4 NEAR HERE}

\section{RESULTS}

Table 4 reports the two stage regression model with Probit estimates for export propensity in column 1 and linear regression results in column 2. Overall the equations provide a relatively robust and reliable description of the data and are for the most part supportive of the hypotheses.

The three variables associated with subsidiary-specific advantages are all significantly associated with export propensity. The geographic distance of the parent MNE 
from the host country market is found to be positively and significantly associated with export propensity thus supporting hypothesis H1. Subsidiaries from distant origins are thus more likely to export; which we have argued is due to their relative advantages within the MNE for serving regional markets. Moreover, establishment of the affiliate by acquisition rather than Greenfield entry is positively and significantly associated with export propensity, supporting hypothesis H2. This supports our argument that acquired resources may be important for developing subsidiary-specific advantages and thus export propensity.

The size of the parent MNE is negatively associated with both export propensity and intensity. This effect is significant in the case of export propensity, showing support for hypothesis H3a. Hence subsidiaries of large MNEs are less likely to export, which we have argued arises from their higher degree of specialization with many subsidiaries taking the role of serving a specific local market, while the MNE has sufficient alternative means to serve these export markets. The effect of parent size is, however, not significant for export intensity, such that we obtain no support for $\mathrm{H} 3 \mathrm{~b}$, which suggests that parent resources may be less important at this second stage.

An important aspect of our theorizing concerns the impact of institutions on export propensity and intensity. We hypothesized that the effect would be different for export intensity and propensity and this is confirmed by the regressions. Thus the economic freedom index variable is significantly negatively associated with the intensity of exporting by the affiliate, providing support for hypothesis $\mathrm{H} 4 \mathrm{~b}$, while it is positive but not significant with respect to export propensity. Our findings are therefore consistent with $\mathrm{H} 4 \mathrm{a}$, but do not quite provide statistically significant support for it. Hence, we conclude that those subsidiaries operating in such an efficient market environment emphasize domestic sales growth relative to export growth, though such an environment may not attract more export oriented investors.

With respect to the control variables, subsidiaries exporting to their parent MNEs also export more overall, as would be expected, yet the coefficient of 0.46 is significantly lower than 1 (at $1 \%$ confidence level), suggesting that there may be a crowding out between intra and inter-firm exports. Other country specific factors are not found to be important in the 
Estrin, S., Meyer, K.E., Wright, M. \& Foliano, F. (2008): Export Propensity and Intensity of

Subsidiaries in Emerging Economies, International Business Review, (IBR, forthcoming).

export, as the host country GDP is negatively associated with export intensity, perhaps because of export opportunities arising from domestic markets, but not statistically significant. ${ }^{5}$ The intensity of domestic competition, however, has a significant effect in encouraging export intensity, albeit that it has no effect on export propensity.

We find a significant negative relationship between the prior experience of the manager with the parent company and the propensity to export. We also find a significant positive relationship between the industry dummies and export propensity, indicating that firms in manufacturing are more likely to export than affiliates in the service sector, but such differences are not significant for export intensity. Thus, controlling for the fact that manufacturing firms are more likely than service firms to export, we find that the amount exported in the two sectors is not significantly different.

The Mills ratio is not significant in the equation, which indicates that the errors in the two stages of the equation are in fact uncorrelated. Hence in our dataset there would not have been omitted variable bias if the two equations had been estimated separately. However, this was still the appropriate estimation process given that the potential for bias existed.

\section{DISCUSSION AND LIMITATIONS}

The theory of the MNE suggests that MNEs set up international subsidiaries when the combination of ownership, location and internalization considerations indicate that the subsidiary would attain competitive advantages in its markets (Dunning, 1998) and thus be able to overcome the liability of foreignness (Zaheer, 1995). We have extended this with the argument that subsidiaries create subsidiary-specific advantages (Rugman \& Verbeke, 2001), which in turn determine the exporting behavior of the subsidiary. In particular, the relative position of subsidiaries with the network of an MNE is crucial to determine which subsidiary is serving any given market. We find that subsidiaries with relative advantages within this

\footnotetext{
${ }^{5}$ In separate regressions we examined the possibility of a special effect in Poland and Hungary arising from the dynamics of the European Union accession process, but a dummy thus included was not statistically significant.
} 
network arising from geographic location (H1), acquired resources (H2) and small scale of the parent MNE (H3a) are more likely to export.

Subsidiaries, however, develop their sales in domestic and export markets, and their relative priority for these markets is strongly influenced by the local context, especially the institutional framework. Thus, we find that under favorable institutional conditions, that is higher levels of economic freedom, subsidiaries prioritize development of local markets at the expense of export growth as suggested by hypothesis $\mathrm{H} 4 \mathrm{~b}$, that is they have lower export intensity. On the other hand, poor institutions in a host economy might reduce the attractive as a location for export-oriented ventures. (H4a). This hypothesis cannot be refuted by the data but is not found to be statistically significant at the required level.

Economic freedom includes integration into the world economy. For example, all six countries engaged in substantial trade liberalization over the 1990s, though at different speeds. The impact of these different institutional factors and trade agreements is picked up in our economic freedom index. It suggests that trade liberalization helps to attract export oriented investors, but may not stimulate investors who are already present to raise their share of exports.

One might expect that the institutional variables in addition moderate the effects of subsidiary specific advantages in creating exports propensity or intensity. We have tested for this possibility empirically by interacting economic freedom with, respectively, geographic distance, acquisition and parent size, but found none of these interactions to be statistically significant (regressions not reported). However, this issue merits further research.

Hence our empirical analysis demonstrates that subsidiary exports are indeed associated with subsidiary-specific advantages arising from the relative position of the subsidiary in the network of the parent MNE. Thus, the concept of subsidiary-specific advantages provides a useful perspective to advance the theory of the multinational enterprise. While Rugman and Verbeke (2001) have advanced the concept by outlining how such subsidiary-specific advantages may be created, we outline how they may shape the pattern of exports generated by subsidiaries, and thus by a network of subsidiaries affiliated with an 
Estrin, S., Meyer, K.E., Wright, M. \& Foliano, F. (2008): Export Propensity and Intensity of Subsidiaries in Emerging Economies, International Business Review, (IBR, forthcoming).

MNE. Our analysis thus provides three insights that should be integrated in future theorizing on MNEs: (a) intensity and propensity of exports are driven by different sets of determinants, and thus need separate empirical and theoretical treatment; (b) Subsidiary-specific advantages drive export propensity; and (c) institutional development negatively affects export intensity.

\section{Limitation and Future Research}

A number of potential limitations of the paper may be addressed by future research. First, while there are several measures of the institutional environment, this study focused only on one, the economic freedom index. Alternatives include the World Bank, Doing Business dataset and the Corruption Perception Index of Transparency International. However, in our estimation we use institutional data for the year in which the subsidiary was created, and these alternative datasets do not go back as far as the Heritage Index. Moreover, the problems of relying on a single index may not be too serious because different measures of the institutional environment are highly co-linear (see Aidis, Estrin, Mickiewicz, 2007).

Second, as the subsidiary is our unit of analysis, so we have collected our variables at this level, and we sought to minimize selection and measurement errors on subsidiary level variables. However, as a consequence, our controls for the characteristics and strategies of the parent firms are less precise than in studies that collect data at the parent firm level. Thus, potentially, our analysis may suffer from omitted variables such as the organizational structure of the parent, i.e. multinational vs. transnational vs. international vs. global strategy (Bartlett \& Ghoshal, 1989; Harzing, 2000). Similarly, the characteristics of the acquired firms may usefully enrich the analysis of our Hypothesis 3.

Future research might usefully undertake a follow-up study to examine whether the relationships identified here have changed over time as the subsidiary become older. Fourth, while our study utilizes a unique survey-based dataset, further research might also attempt to use firm-level secondary data sources, although these are recognized as hard to obtain in emerging economies (Hoskisson, et al., 2000). 
Finally, like most studies, only replication studies can establish the generalizability of our findings in other contexts. Part of the novelty of our study is that we include a set of emerging economies that have rarely been examined (Hoskisson, et al., 2000) and exhibit a high variation across our pivotal variable, institutions. However, one could fruitfully separate out the effects of different institutional factors, for example property rights enforcement as compared with trade liberalization or membership of regional trading blocks. To achieve this, future research could fruitfully extend the analysis to larger sets of host countries.

\section{CONCLUSIONS}

In this paper, we have argued that subsidiary-specific advantages evolve in the interplay of global strategy with the local environment, and drive the exporting behavior of MNE subsidiaries. We elaborated this theoretical perspective and furnish empirical evidence. Our findings provide new insights for future theorizing on the MNE subsidiary-specific advantages (Rugman \& Verbeke, 2003) as a component of firm-specific advantages in the context of a network perspective of MNEs (Casson, 2000; Buckley \& Hashai, 2004).

Our results have important implications for both management practice and public policy. Managers may find the notion of subsidiary specific advantages useful in defining and developing subsidiary mandates that extend beyond the host country. We have argued that subsidiary-specific advantages need to provide a competitive edge vis-à-vis three groups of competitors: local firm in the target market, local firms in the host country and other subsidiaries of the same MNE. Moreover we have demonstrated differential impacts of key decision parameters on the propensity to export and the intensity of exporting. This distinction may help clarifying managerial decision making processes.

Finally, policy makers often see MNEs as a vehicle to promote exports from emerging economies. Our results suggest that they would be more likely to achieve this objective if they attract foreign investors from distant origins and from small parent firms. The significance of the economic freedom index suggests that governments should focus attention on strengthening their own local institutional infrastructure if they wish to attract 
Estrin, S., Meyer, K.E., Wright, M. \& Foliano, F. (2008): Export Propensity and Intensity of Subsidiaries in Emerging Economies, International Business Review, (IBR, forthcoming).

foreign firms to export from their local subsidiaries, but should not expect existing subsidiaries to increase their export focus. 
Estrin, S., Meyer, K.E., Wright, M. \& Foliano, F. (2008): Export Propensity and Intensity of Subsidiaries in Emerging Economies, International Business Review, (IBR, forthcoming).

\section{REFERENCES}

Aidis, R, Estrin, S. \& Mickiewicz, T. 2007. Entrepreneurship in emerging markets: Which institutions matter? Academy of Management conference, Philadelphia.

Anand, J. \& Delios, A. 2002. Absolute and relative resources as determinants of international acquisitions. Strategic Management Journal, 23: 119-134.

Andersson, U., Forsgren, U. \& Pedersen, T. 2001. Subsidiary performance in multinational corporations: The importance of technology embeddedness. International Business Review, 10: 3-23.

Aulakh, P., Kotabe, M. \& Teegen, H. 2000. Export strategies and performance of firms from emerging economies: Evidence from Brazil, Chile, and Mexico. Academy of Management Journal, 43: 342-361.

Barkema, H. \& Vermeulen, F. 1998. International expansion through start-up or acquisition: A learning perspective. Academy of Management Journal, 41: 7-26.

Barney, J., Wright, M., \& Ketchen, D. 2001. The resource-based view of the firm: Ten years after 1991. Journal of Management, 27: 625-641.

Bartlett, C. \& Ghoshal, S. 1989. Managing across borders. Boston, MA: Harvard Business School Press.

Belderbos, R. 2003. Entry mode, organizational learning, and R\&D in foreign affiliates: evidence from Japanese firms. Strategic Management Journal, 24: 235-259.

Bevan, A.A., Estrin, S., Meyer, K.E. 2004. Institution Building and the Integration of Eastern Europe in International Production, International Business Review 13 43-64.

Birkinshaw, J. 1996. How multinational subsidiary mandates are gained and lost. Journal of International Business Studies 27: 467-495

Birkinshaw, J. \& Hood, N. 1998. Multinational subsidiary evolution: Capabilities and charter change in foreign-owned companies. Academy of Management Review, 23: 773-795.

Bonaccorsi, A. 1992. On the relationship between firm size and export intensity. Journal of International Business Studies, 23: 605-636.

Brouthers, K.D. \& Brouthers, L.E. 2003. Why service and manufacturing entry mode choices differ: The influence of transaction cost factors, risk, and trust. Journal of Management Studies, 40: 1179-1204.

Brouthers, K. D., \& Hennart, J.-F. 2007. Boundaries of the firm: Insights from international entry mode research. Journal of Management, 33: 395-425.

Buckley P.J. \& Casson, M.C. 1976. The future of the multinational enterprise. London: Macmillan.

Buckley P.J. \& Casson, M.C. 1998. Analyzing foreign market entry strategies: Extending the internalization approach. Journal of International Business Studies, 29: 539-562. 
Estrin, S., Meyer, K.E., Wright, M. \& Foliano, F. (2008): Export Propensity and Intensity of Subsidiaries in Emerging Economies, International Business Review, (IBR, forthcoming).

Buckley, P.J. \& Hashai, N. 2004. A global system of firm boundaries. Journal of International Business Studies, 35: 33-45.

Caves, R. 1974. International trade, international investment and imperfect markets. Princeton: Princeton University Press.

Cavusgil, S.T. \& Nevin, J.R. 1981. Internal Determinants of Export Marketing Behavior: An Empirical Investigation, Journal of Marketing Research 18: 114-119.

Casson, M.C. 2000. The economics of international business: A new research agenda, Cheltenham: Edward Elgar.

Chung, C. \& Beamish, P. 2005. The impact of institutional reforms on characteristics and survival of foreign subsidiaries in emerging economies. Journal of Management Studies, 42: 35-62.

Das, S., Roberts M.J. \& Tybout, J.R. 2007. Market entry costs, producer heterogeneity, and export dynamics. Econometrica, 75: 837-873.

Davis, L.N. \& Meyer, K.E. 2004. Subsidiary research and development, and the local environment. International Business Review, 13: 359-382.

Dawar, N. \& Frost, T. 1999. Competing with giants: Survival strategies for local companies in emerging markets. Harvard Business Review, March-April: 119-129.

Delios, A. \& Henisz, W. 2000. Japanese firms' investment strategies in emerging economies. Academy of Management Journal, 43: 305-323.

Djankov, S. \& Murrell, P. 2002. Enterprise restructuring in transition: A quantitative survey. Journal of Economic Literature, 40: 739-792.

Dominguez, L. V. \& Sequeira, C.G. 1993. Determinants of LDC exporters' performance: A cross-national study. Journal of International Business Studies, 24: 19-40.

Dunning, J.H. 1998. Location and the multinational enterprise: a neglected factor? Journal of International Business Studies, 29: 45-66.

Dunning, J.H. \& Lundan, S. 1998. The geographical sources of competitiveness of multinational enterprises: an econometric analysis, International Business Review 7: 115-133.

Dunning, J.H. \& Lundan, S. 2008. Institutions and the OLI paradigm of the multinational enterprise, Asia Pacific Journal of Management, in press (DOI: 10.1007/s10490-0079074-z).

Ellis, P.D. 2007. Distance, dependence and diversity of markets: Effects on market orientation. Journal of International Business Studies, 38: 374-386.

Estrin, S. and Meyer, K.E., eds. 2004. Investment Strategies in Emerging Markets, Cheltenham: Edward Elgar. 
Filatotchev, I., Dyomina, N., Wright, M. \& Buck, T. 2001. Effects of post-privatization governance and strategies on export intensity in the former Soviet Union. Journal of International Business Studies, 32: 853-871.

Filatotchev, I., Stephan, J. \& Jindra, B. 2008. Ownership structure, strategic controls and exporting of foreign-invested firms in transition economies. Journal of International Business Studies, forthcoming.

Fiol, C.M. \& Lyles, M. 1985. Organizational learning. Academy of Management Review, 10: 803-813.

Frost, T. S., Birkinshaw, J., \& Ensign, P. 2002. Centers of excellence in multinational corporations. Strategic Management Journal, 23: 997-1018.

Ghemawat, P. 2007. Redefining Global Strategy: Harvard Business School Press.

Gomes-Casseres, B. 1990. Firm ownership preferences and host government restrictions: An integrated approach. Journal of International Business Studies, 21: 1-22.

Greenaway, D., Sousa, N. \& Wakelin, K. 2004. Do firms learn to export from multinationals? European Journal of Political Economy 20: 1027-1043.

Hair, J.F. Anderson, R.E.; Tatham, R.L. \& Black, W.C. 1998. Multivariate Data Analysis. Upper Saddle River: Prentice-Hall.

Harzing, A.W.K. 2000. An Empirical Analysis and Extension of the Bartlett and Ghoshal Typology of Multinational Companies. Journal of International Business Studies, 31: 101-120.

Harzing, A.W.K. \& Nooderhaven, N. 2006. Geographical distance and the role and management of subsidiaries: The case of subsidiaries down-under. Asia Pacific Journal of Management, 23: 167-185.

Henisz, W. 2003. The power of the Buckley and Casson thesis: The ability to manage institutional idiosyncracies. Journal of International Business Studies, 34: 173-184.

Hennart, J.F. \& Park, Y.R. 1993. Greenfield vs. Acquisition: The Strategy of Japanese Investors in the United States. Management Science, 39: 1054-1070.

Hoskisson, R., Eden, L, Lau, C-M. \& Wright, M. 2000. Strategy in emerging economies. Academy of Management Journal, 43: 249-267.

La Porta, R., Lopez-de-Silanes, F., Shleifer, A. \& Vishny, R. 1998. Law and finance. Journal of Political Economy, 106: 1113-1155.

Lee, C. \& Beamish, P. 1995. The characteristics and performance of Korean joint ventures in LDCs. Journal of International Business Studies, 26: 637-654.

Leonidou, L. C. \& Katsikeas, C.S. 1996. The export development process: An integrative review of empirical models. Journal of International Business Studies, 27: 517-552. 
Lockett, A., Wright, M., Burrows, A., Scholes, L. \& Paton, D. 2008. The export intensity of venture capital backed companies. Small Business Economics, forthcoming (DOI: 10.1007/s11187-008-9109-y).

London, T. \& Hart, S. 2004. Reinventing strategies for emerging markets: beyond the transnational model. Journal of International Business Studies, 35: 350-370.

Luo, Y. 2003. Market-seeking MNEs in an emerging market: How parent-subsidiary links shape overseas success. Journal of International Business Studies, 34: 290-309.

Luo, Y. \& Peng, M. W. 1999. Learning to compete in a transition economy: Experience, environment, and performance. Journal of International Business Studies, 30: 269296.

Majocchi, A., Bacchiocchi E. \& Mayrhofer, U. 2005. Firm size, business experience and export intensity in SMEs: A longitudinal approach to complex relationships, International Business Review, 14: 719-738.

Meyer, K. E. 2001. Institutions, transaction costs, and entry mode choice in Eastern Europe. Journal of International Business Studies, 32: 357-367.

Meyer, K.E. \& Estrin, S. eds. 2008. Acquisition Strategies in European Emerging Economies, Basingstoke: Palgrave-Macmillan.

Meyer, Klaus E.; Estrin, Saul; Bhaumik, Sumon K. \& Peng, Mike W. 2008. Institutions, resources, and entry strategies in emerging economies, Strategic Management Journal, in press.

Meyer, K.E. \& Nguyen, H.V. 2005. Foreign investment strategies and sub-national institutions in emerging markets: Evidence from Vietnam, Journal of Management Studies, 42: 63-93.

Meyer, K. E. \& Peng, M.W. 2005. Probing theoretically into Central and Eastern Europe: Transactions, resources and institutions. Journal of International Business Studies, 36: 600-621.

Narayanan, V.K. \& Fahay L. 2005. The relevance of the institutional underpinnings of Porter's Five Forces framework to emerging economies, Journal of Management Studies 42; 207- 223.

North, D. C. 1990. Institutions, institutional change, and economic performance. Cambridge and New York: Cambridge University Press.

Ozawa, T. 1979. International investment and industrial structure: New theoretical implications from the Japanese experience. Oxford Economic Papers, 31: 72-92.

Peng, M. W. 2003. Institutional transitions and strategic choices. Academy of Management Review, 28: 275-296. 
Podsakoff, P. M., MacKenzie, S. B., Lee, Y-L \& Podsakoff, N. P. 2003. Common method bias in behavioral research: A critical review of the literature and recommended remedies. Journal of Applied Psychology, 88: 879-903.

Rugman, A. 1996. The theory of the multinational enterprise, Cheltenham: Edward Elgar.

Rugman, A. \& Verbeke, A. 2001. Subsidiary-specific advantages in multinational enterprises, Strategic Management Journal, 22: 237-250.

Rugman, A. \& Verbeke, A. 2003. Extending the theory of the multinational enterprise: internalization and strategic management perspectives, Journal of International Business Studies, 34: 125-137.

Uhlenbruck, K. 2004. Developing acquired foreign subsidiaries: The experience of MNEs in transition economies. Journal of International Business Studies, 35: 109-123.

Uhlenbruck, K. \& De Castro, J. 2000. Foreign acquisitions in central and eastern Europe: outcomes of privatization in transition economies. Academy of Management Journal, 43: 381-402.

Wagner, J. 2007. Exports and productivity: A survey of the evidence from firm-level data. World Economy 30: 60-82.

Wright, M., Filatotchev, I., Hoskisson, R. \& Peng, M. 2005. Strategy research in emerging economies: challenging the conventional wisdom. Journal of Management Studies, 42:1-35.

Wu., F., Sinkovics, R.R., Cavusgil, S.T., \& Roath, A.S. 2007. Overcoming export manufacturers' dilemma in international expansion. Journal of International Business Studies, 38: 283-302.

Zaheer, S. 1995. Overcoming the liability of foreignness. Academy of Management Journal, 38: $341-363$. 
Estrin, S., Meyer, K.E., Wright, M. \& Foliano, F. (2008): Export Propensity and Intensity of Subsidiaries in Emerging Economies, International Business Review, (IBR, forthcoming).

Table 1: Variable definitions

\begin{tabular}{|c|c|}
\hline Variable & Definition \\
\hline \multicolumn{2}{|l|}{ Dependent variables } \\
\hline Export propensity & $\begin{array}{l}\text { Dummy variable taking the value } 1 \text { if the affiliate exports greater } 1.5 \% \\
\text { of sales and } 0 \text { otherwise (source: questionnaire) }\end{array}$ \\
\hline Export intensity & Export sales as $\%$ of total sales of affiliate (source: questionnaire) \\
\hline \multicolumn{2}{|l|}{ Global strategy } \\
\hline $\begin{array}{l}\text { Geographical distance } \\
\text { (H1) }\end{array}$ & $\begin{array}{l}\text { Log of the geographic distance between the home country of the } \\
\text { parent MNE and the host country, in } 1000 \text { kilometers. Data source: } \\
\text { website of the US Department of Agriculture } \\
\text { http://www.wcrl.ars.usda.gov/cec/java/lat-long.htm. }\end{array}$ \\
\hline Acquisition (H2) & $\begin{array}{l}\text { Dummy variable taking the value of } 1 \text { if the affiliate was initially } \\
\text { established by partial or full acquisition, and } 0 \text { otherwise. (source: } \\
\text { questionnaire) }\end{array}$ \\
\hline Parent size (H3) & $\begin{array}{l}\text { Log of Worldwide employment of the foreign parent (source: } \\
\text { questionnaire) }\end{array}$ \\
\hline \multicolumn{2}{|l|}{ Local Context } \\
\hline Economic freedom $(\mathrm{H} 4)$ & $\begin{array}{l}\text { Economic freedom index developed by the Heritage Foundation. Data } \\
\text { refer to the year closest to the time of entry. High values are associated } \\
\text { with an institutional framework providing greater economic freedom. } \\
\text { (www.heritage.org/index) }\end{array}$ \\
\hline \multicolumn{2}{|l|}{ Controls } \\
\hline Export to Parent & $\begin{array}{l}\text { The share of exports that is directed at other units of the parent MNE } \\
\text { (source: questionnaire) }\end{array}$ \\
\hline Parent experience & $\begin{array}{l}\text { Dummy variable taking the value of } 1 \text { if the foreign investor had prior } \\
\text { commercial experience in the host country and } 0 \text { otherwise. (source: } \\
\text { questionnaire) }\end{array}$ \\
\hline Parent R\&D & $\begin{array}{l}\text { Foreign parent's expenditure on R\&D as a percentage of sales (seven } \\
\text { point categorical variable where } 1=0-0.5 \% ; 2=0.5-1 \% ; 3=1-2 \% ; 4= \\
2-4 \% ; 5=4-8 \% ; 6=8-15 \% ; 7=\text { over } 15 \% \text { ) (source: questionnaire) }\end{array}$ \\
\hline Manager experience & $\begin{array}{l}\text { Dummy variable taking the value of } 1 \text { if the manager of the affiliate } \\
\text { had worked for the parent company }\end{array}$ \\
\hline Heavy manufacturing & $\begin{array}{l}\text { Dummy variable taking the value } 1 \text { if the affiliate is in a heavy } \\
\text { manufacturing sector and } 0 \text { otherwise. }\end{array}$ \\
\hline Light manufacturing & $\begin{array}{l}\text { Dummy variable taking the value } 1 \text { if the affiliate is in a light } \\
\text { manufacturing sector and } 0 \text { otherwise. }\end{array}$ \\
\hline Host country GDP & Host country GDP \\
\hline Competition & $\begin{array}{l}\text { Seven point scale item for number of domestic competitors in the main } \\
\text { market, scaled from } 1=\text { none to } 7=\text { over } 10 \text {. (source: questionnaire). }\end{array}$ \\
\hline Parent GDP p.c. & Parent's country GDP per capita \\
\hline
\end{tabular}


Estrin, S., Meyer, K.E., Wright, M. \& Foliano, F. (2008): Export Propensity and Intensity of Subsidiaries in Emerging Economies, International Business Review, (IBR, forthcoming).

Table 2: Summary statistics

\begin{tabular}{lllllll}
\hline Variable & Obs & Mean & Std. Dev. & Min & Max & VIF \\
Export propensity & 494 & 0.65 & 0.48 & 0 & 1 & \\
Export intensity & 494 & 31.76 & 37.30 & 0 & 100 & \\
Geographic distance & 494 & 5814.84 & 4193.27 & 163.53 & 14256 & \\
Acquisition & 494 & 0.17 & 0.38 & 0 & 1 & \\
Parent Size & 494 & 8.34 & 2.39 & 0 & 13.001 & 1.24 \\
Economic freedom & 494 & 53.35 & 8.81 & 38.10 & 67.30 & 1.21 \\
Export to parent & 490 & 6.83 & 22.55 & 0 & 200 & 1.04 \\
Parent experience & 494 & 0.53 & 0.50 & 0 & 1 & 1.27 \\
Parent R\&D & 494 & 3.19 & 2.00 & 0 & 7 & 1.06 \\
Manager experience & 494 & 0.32 & 0.47 & 0 & 1 & 1.06 \\
Heavy Manufacturing & 494 & 0.40 & 0.49 & 0 & 1 & 1.34 \\
Light Manufacturing & 494 & 0.16 & 0.37 & 0 & 1 & 1.36 \\
Host country GDP $\left(10^{9}\right)$ & 494 & 127 & 110 & 15,9 & 457 & 1.11 \\
Competition & 494 & 3.69 & 1.23 & 1 & 5 & 1.08 \\
Parent GDP/pc & 494 & 22285.11 & 9327.51 & 278.10 & 43411.80 & 1.16 \\
Nonselection Hazard & 494 & 0.57 & 0.25 & 0.08 & 1.31 & \\
\hline
\end{tabular}


Estrin, S., Meyer, K.E., Wright, M. \& Foliano, F. (2008): Export Propensity and Intensity of Subsidiaries in Emerging Economies, International Business Review, (IBR, forthcoming).

\section{Table 3: Correlation matrix}

\begin{tabular}{|c|c|c|c|c|c|c|c|c|c|c|c|c|c|c|}
\hline & & 1 & 2 & 3 & 4 & 5 & 6 & 7 & 8 & 9 & 10 & 11 & 12 & 13 \\
\hline 1 & Geographic distance (H1) & 1 & & & & & & & & & & & & \\
\hline 2 & Acquisition (H2) & 0.07 & 1 & & & & & & & & & & & \\
\hline 3 & Parent size (H3) & $0.19^{*}$ & $0.11^{*}$ & 1 & & & & & & & & & & \\
\hline 4 & Economic freedom $(\mathrm{H} 4)$ & $0.22^{*}$ & $0.35^{*}$ & $0.17^{*}$ & 1 & & & & & & & & & \\
\hline 5 & Export to Parent & 0.00 & 0.00 & 0.01 & -0.01 & 1 & & & & & & & & \\
\hline 6 & Parent experience & $0.33^{*}$ & 0.05 & $0.35^{\star}$ & $0.19^{*}$ & -0.01 & 1 & & & & & & & \\
\hline 7 & Parent R\&D & $0.11^{*}$ & $0.13^{*}$ & 0.06 & $0.13^{*}$ & 0.04 & $0.14^{*}$ & 1 & & & & & & \\
\hline 8 & Manager experience & 0.04 & -0.08 & 0.03 & $-0.13^{*}$ & -0.03 & 0.04 & -0.02 & 1 & & & & & \\
\hline 9 & Heavy manufacturing & 0.06 & 0.06 & 0.04 & $-0.10^{*}$ & $0.11^{*}$ & -0.01 & $0.11^{*}$ & 0.05 & 1 & & & & \\
\hline 10 & Light manufacturing & $-0.09^{*}$ & 0.02 & -0.04 & $-0.11^{*}$ & -0.06 & -0.06 & -0.01 & 0.04 & $-0.36^{*}$ & 1 & & & \\
\hline 11 & Host GDP & $0.30^{*}$ & -0.06 & -0.01 & -0.04 & 0.00 & $0.11^{*}$ & 0.02 & -0.04 & 0.08 & -0.06 & 1 & & \\
\hline 12 & Competition & 0.03 & -0.08 & -0.00 & -0.01 & $-0.11^{*}$ & 0.05 & -0.05 & 0.02 & $-0.14^{*}$ & -0.01 & -0.02 & 1 & \\
\hline 13 & Parent GDP p.c. & $0.25^{*}$ & 0.08 & 0.08 & $0.10^{*}$ & 0.06 & $0.09^{*}$ & 0.08 & $-0.13^{*}$ & -0.00 & $-0.19^{*}$ & $0.19^{*}$ & -0.05 & 1 \\
\hline
\end{tabular}

Note: $*=$ significant at $5 \%$ level 
Estrin, S., Meyer, K.E., Wright, M. \& Foliano, F. (2008): Export Propensity and Intensity of Subsidiaries in Emerging Economies, International Business Review, (IBR, forthcoming).

Table 4: Heckman 2-step estimation of export propensity and intensity

\begin{tabular}{|c|c|c|}
\hline & Step 1 & Step 2 \\
\hline & $\begin{array}{l}\text { Export } \\
\text { propensity }\end{array}$ & $\begin{array}{l}\text { Export } \\
\text { intensity }\end{array}$ \\
\hline \multicolumn{3}{|c|}{ Resource Position of the Subsidiary } \\
\hline Geographic distance (H1) & $\begin{array}{l}5.01 E-05 * * * \\
(1.69)\end{array}$ & --- \\
\hline Acquisition (H2) & $\begin{array}{l}0.40 * * \\
(0.19)\end{array}$ & --- \\
\hline Parent size $(\mathrm{H} 3)$ & $\begin{array}{l}-0.08 * * * \\
(0.03)\end{array}$ & $\begin{array}{l}-1.34 \\
(1.03)\end{array}$ \\
\hline \multicolumn{3}{|l|}{ Institutions } \\
\hline Economic freedom $(\mathrm{H} 4)$ & $\begin{array}{l}0.012 \\
(0.007)\end{array}$ & $\begin{array}{l}-0.85 * * * \\
(0.29)\end{array}$ \\
\hline \multicolumn{3}{|l|}{ Controls } \\
\hline Exports to Parent & --- & $\begin{array}{l}0.45^{* * *} \\
(0.07)\end{array}$ \\
\hline Parent experience & $\begin{array}{l}0.03 \\
(0.13)\end{array}$ & $\begin{array}{l}-9.87 * * \\
(4.28)\end{array}$ \\
\hline Parent R\&D & $\begin{array}{l}0.028 \\
(0.031)\end{array}$ & $\begin{array}{l}-0.23 \\
(0.97)\end{array}$ \\
\hline Manager experience & $\begin{array}{l}-0.439 * * * \\
(0.131)\end{array}$ & $\begin{array}{l}-2.30 \\
(5.47)\end{array}$ \\
\hline Industry: Heavy Manufacturing & $\begin{array}{l}0.557 * * * \\
(0.140)\end{array}$ & $\begin{array}{l}-8.67 \\
(6.52)\end{array}$ \\
\hline Industry: Light Manufacturing & $\begin{array}{l}0.555^{* * *} \\
(0.189)\end{array}$ & $\begin{array}{l}-2.75 \\
(7.40)\end{array}$ \\
\hline Host country GDP & $\begin{array}{l}-6.32 \mathrm{E}-13 \\
(5.77 \mathrm{E}-13)\end{array}$ & $\begin{array}{l}-1.99 \mathrm{E}-11 \\
(1.84 \mathrm{E}-11)\end{array}$ \\
\hline Competition & $\begin{array}{l}-0.004 \\
(0.050)\end{array}$ & $\begin{array}{l}-3.05^{* *} \\
(1.50)\end{array}$ \\
\hline Parent country GDP/pc & $\begin{array}{l}-8.34 \mathrm{E}-06 \\
(7.01 \mathrm{E}-06)\end{array}$ & $\begin{array}{l}3.34 \mathrm{E}-04 \\
(2.12 \mathrm{E}-04)\end{array}$ \\
\hline Constant & $\begin{array}{l}0.116 \\
(0.527)\end{array}$ & $\begin{array}{l}128.24 * * * \\
(22.51)\end{array}$ \\
\hline Mills & & \\
\hline Observations & & \\
\hline Censored obs & & \\
\hline Uncensored obs & & \\
\hline Wald chi2(18) & & \\
\hline
\end{tabular}

Standard errors in parentheses

$*$ significant at $10 \%$; * significant at $5 \%, * * *$ significant at $1 \%$. 
Figure 1: Subsidiary Export Propensity and Intensity

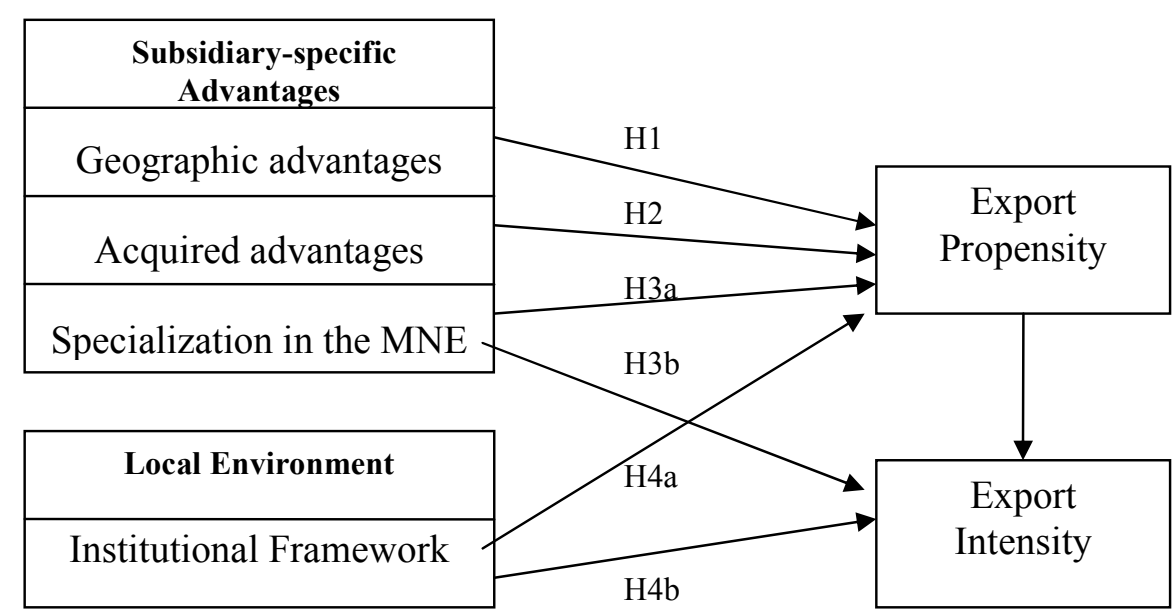

Figure 2: Exports from Subsidiaries

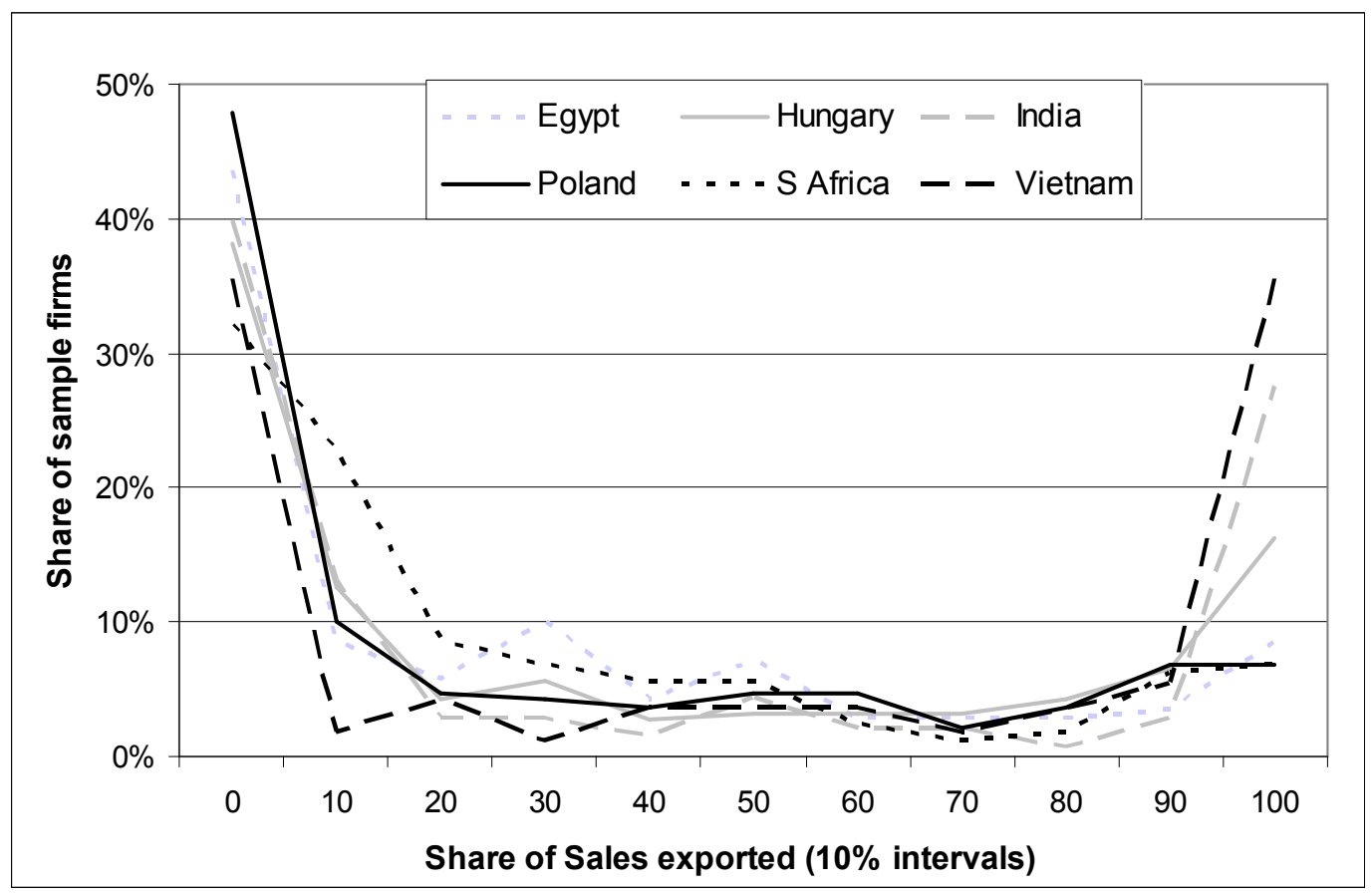

